\title{
Impact of Corporate Governance on Effective Corporate Tax Rates Among Listed Firms in Kenya
}

\author{
Peter Rawlings Osebe* \\ Department of Accounting and Finance, University of Kabianga, Kenya \\ Joseph Kiprono Kirui \\ Department of Marketing and Management Science, University of Kabianga, Kenya \\ Isaac Kiprotich Naibei \\ Department of Accounting and Finance, University of Kabianga, Kenya
}

\begin{abstract}
Corporate tax is not only an important source of revenue to governments around the world but is also used to achieve a number of fiscal objectives. On the other hand, Corporation tax represents a significant expense to companies thereby impacting on major corporate decisions. Understanding factors that affect the effective corporate tax rates is therefore important not only to corporations but also to governments and other policy makers. Despite the well documented corporate tax leakages across the world, widening budget deficits and ballooning public debt in Kenya, limited studies have been conducted to investigate the impact of corporate governance on effective tax rates among the NSE listed firms. The purpose of this study was therefore to investigate the impact of board size, board independence, board gender diversity and corporate ownership structure on effective corporate tax rates among listed firms in Kenya between 2011 and 2017. The study employed longitudinal research design. A sample of 40 firms were purposively selected from the 67 listed firms in Kenya as at $31^{\text {st }}$ December, 2017.Data was extracted from the published financial statements of the sampled firms. Data was analyzed with the aid of STATA software. The findings of the study show that board size, board independence and board gender diversity has a positive and significant effect on effective tax rates. On the other hand, ownership structure has a negative and significant effect on effective tax rates. The study therefore concludes that corporate governance has a significant impact on effective tax rates among listed firms in Kenya and recommends that policy makers, investors and corporate executives consider this fact when making their tax policies and decisions.
\end{abstract}

Keywords: Corporate governance, Effective tax rate, listed firms, Kenya.

DOI: $10.7176 /$ RJFA/10-18-04

Publication date:September $30^{\text {th }} 2019$

\section{INTRODUCTION}

Corporate tax is one of the main sources of government revenue especially for developing economies where alternative sources of income are thin (Crivelli, Mooij and Keen, 2016). Apart from being a source of revenue, corporate tax is also used by governments in fiscal management of the economy in such areas like foreign direct investments. To achieve these objectives, governments set statutory corporate tax rates at which corporations are expected to pay their taxes (Crivelli et al, 2016).

However, statutory corporate tax rates do not provide a complete picture of a firm's total tax expense since a firm's tax cost is obtained by applying a series of deferrals, accruals and other deductions to the pre -tax income (Ribeiro, Cerqueira and Brandao, 2015). These adjustments are brought about due to differences between accounting and tax treatment of certain items in the financial statements. Thus effective tax rates (ETR) provide a more reliable and realistic measure of a firm's tax burden than the statutory rates.

Corporate tax plays an important role in corporate financial decisions (Graham, 2003). Some of the financial decisions affected by corporate income tax include capital budgeting decisions, capital structure decisions and dividend policy. Nekesa, Namusonge and Makokha (2017) established that corporate income tax has a significant positive relationship with financial performance of firms listed on the Nairobi Securities Exchange (NSE) thus suggesting the influence corporate tax has on major corporate decisions.

Since tax represents a significant expense to a firm which in turn affects its performance, firms will always look for ways of reducing their tax burden by lowering their effective tax rates. A study by Congressional Budget Office (GAO, 2008) revealed that Effective tax rates are always lower than the statutory tax rates. Similarly a study by Pomerleau and Jahnsen (2017) and Fernandez-Rodriguez, Garcia-Fernandez and Martinez-Arias (2019) also shows that ETRs are always lower than the statutory tax rates.

Lower effective tax rates benefit a company through cash savings which affords it the opportunity to make new investments which in turn enhances the value of the firm. Consequently, shareholders' wealth is maximized in terms of increased share price and higher dividends (Annuar, Salihu and Sheikh-Obid, 2014). Lim (2011) also cites the benefit of lower cost of debt brought about by lower effective tax rate as a result of reduced default risk 
and increased financial slack. The benefits of lower ETR do not only accrue to shareholders but also to management team who in most cases receive compensations for their work in reducing a company's tax liabilities.

While a lower effective tax rate is beneficial to the company and her shareholders in terms of tax savings, the costs associated with it may be too large to bear. Annuar et al. (2014) list these costs to include the potential penalty imposed by tax authorities, agency costs of rent extraction, fall in a company's share price and damage to company's reputation and legitimacy. A specific study by Hanlon and Slemrod (2009) established that news about corporate tax aggressiveness leads to a negative effect on the stock prices of these companies. On the other hand, companies reporting higher effective corporate tax rates record an increased market value (Desai, Dyck and Zingales, 2007).

While past studies have generally considered the impact of firm's specific characteristics such as firm size, capital structure, profitability and asset mix on effective tax rates, most of these studies have failed to provide a full picture of what exactly determines effective tax rates among corporations that are characterized by separation of ownership from control. These studies generally assume that companies make their tax decisions without considering agency problem and ignore the role the board of directors could have on a company's tax strategy (Ribeiro et al., 2015). This has led to calls by scholars to consider the impact of corporate governance on effective corporate tax rates.

Corporate governance has been hailed as a way to solve agency problem emanating from separation of ownership and control. As Shleifer and Vishny (1997) observe, the board of directors have a duty to protect the interest of shareholders. This is because the board has the power to recruit, dismiss and compensate top management as well as to approve and monitor important company decisions. This view is shared by Bhagat and Bolton (2008) who state that the role of the board is to protect the company shareholders by monitoring management and that the effectiveness of the board in doing this depends on its composition.

Corporate tax compliance is without a doubt, critical to any governments' fiscal policy. This is because most of the tax revenues are collected or paid by corporations (Joulfaian, 2000). As Crivelli et al. (2016) found out, developing countries tend to be more reliant on the corporate income tax as a share of all tax revenue than are higher income countries. ICPAK (2016) established that tax revenue accounts for over ninety per cent of Kenya's revenue portfolio with income tax identified as the major contributor to tax revenue accounting for over fourty five percent. These findings corroborate the earlier findings by Mutua (2012).

In the recent past, Kenya has witnessed a widening budget deficit and a ballooning public debt that has caused a lot of concern among policy makers and the public in general. Central Bank of Kenya figures show that public debt has risen from 1.3 Trillion Kenya shillings to over 4.5 Trillion in the period 2011 to 2017. The same figures also indicate that budget deficit has grown from a low of 156 Billion Kenya shillings in 2011 to stand at a staggering 737 Billion in the year 2017.

Listed firms being among the largest companies in Kenya make a significant contribution to tax revenue. The government must therefore ensure it gets a steady and fair share of revenue from these taxpayers through the enactment of appropriate legal and regulatory framework to govern their taxation. Equally, Corporations have a keen interest in the corporate tax architecture in their areas of jurisdiction since it has a huge bearing on major corporate decisions.

The main focus of this study was therefore to investigate the impact of corporate governance on effective corporate tax rates. Specifically, the study investigated the direct impact of board size, board independence, board gender diversity and corporate ownership structure on effective tax rates among listed firms in Kenya.

With this background, the study now proceeds as follows: Section two reviews relevant theoretical and empirical literature and develops hypotheses, section three presents the research methodology, section four presents and discusses the results, section five gives conclusions and recommendations and the last section suggests areas for further research.

\subsection{LITERATURE REVIEW}

\subsection{Theoretical Review}

Agency theory provided the theoretical framework for this study. The essence of this theory is that in large corporations, there is usually a separation of ownership from management. This is because not all shareholders may be available to run the company and even if they were, there large numbers could hinder them from running the company effectively. They therefore hire persons to help them run the business on their behalf. Thus, their exists an agency relationship where the shareholders are the principals and the managers are the agents (Jensen and Meckling, 1976)

It is expected that managers being the hired agents would take those decisions and actions that are in the best interest of their principals which is to maximize the shareholders wealth. In practice however, managers may pursue their own self-interest at the expense of shareholders. This creates agency conflict or agency problem (Fama and Jensen, 1983).

The mechanism shareholders use to manage the inherent conflict between managers and shareholders is the 
board of directors (Fama and Jensen, 1983 and Eisenhardt, 1989). The board does this by playing both advisory and monitoring role. The effectiveness of the board to play these roles and therefore guarantee shareholders maximum benefits is influenced by several factors such as the size of the board, board independence and board diversity.

Florackis (2008) observes that ownership concentration can also be used to reduce agency problems. The study points out that shareholders with a small stake in the company have little incentive to monitor management as opposed to those with significant stakes who have a keen interest in active and effective monitoring of managers. But an attempt to use ownership concentration as a way to solve agency problem can give rise to another agency conflict, that of majority and minority shareholders. Majority shareholders may use their power and influence to engage in rent extraction activities at the detriment of minority shareholders (Shleifer and Vishney, 1997). As Florackis (2008) argues majority shareholders will benefit from the advantage of reducing the effective tax rate and will require management to fulfill this task but they will actively monitor the process. However, as Chen et al. (2010) contend it is the large shareholders that will suffer the most in terms of potential penalties and reputational costs associated with tax aggressiveness.

The relevance of the Agency Theory in explaining the relationship between corporate governance mechanisms and effective corporate tax rates is best seen in the study conducted by Desai and Dharmapala (2006) in which they found that managers may use effective tax rates to mask their rent extraction activities. They argue that shareholders should discourage tax aggressiveness as part of managing agency problem. Similarly, Desai et al. (2007) observe that opportunistic managers usually structure the company in such a way as to reduce corporate taxes for their private gain.

The board of directors is therefore expected to play its role effectively by doing a cost-benefit analysis of activities aimed at reducing effective tax rates before approving or rejecting them. This will go a long way in protecting shareholders interest hence maximizing the value of the firm. How well the board executes this mandate will to a large extent depend on its composition in terms of size, independence and gender diversity.

\subsection{Empirical Review}

\subsubsection{Board Size and Effective Corporate Tax Rates}

Prior studies have reported mixed and inconclusive findings on the relationship between board size and effective corporate tax rates. For Minnick and Noga (2010), smaller boards contribute to good tax management practices compared to large boards, a fact they attribute to ease in decision making. This ease in decision making by small boards could deny managers an opportunity to mask their rent extraction activities through engagement in excessive tax management practices.

Lanis and Richardson (2011) in a study of the effect of board of director composition on corporate tax aggressiveness found that the level of tax management is significantly affected by board size.

However, Aliani and Zarai (2012a) did not find significant relationship between board size and effective tax rates. Likewise, Khaoula and Ali (2012) using a sample of 300 S\&P firms for periods 1996-2009 found insignificant relationship between the two. This may be attributed to failure by boards to effectively monitor management thereby allowing management to take decisions they deem fit.

Ribeiro, Cerqueira and Brandao (2015) observed that large boards are related to high effective corporate tax rates. This can be explained by the fact that as the size of the board increases, it becomes difficult to arrive at a consensus due to varying opinions. This makes it difficult to execute vital corporate decisions such as tax planning.

Pratama (2017) conducted a study among listed Indonesian companies and obtained results indicating a significant negative relationship between the size of the board and effective tax rates implying the higher the number of directors, the lower the effective tax rate. He attributes this to difficulty in arriving at a consensus thus allowing management to take decisions that benefit themselves. Similarly, Khamoussi, Neifar and Abdelaziz (2016) found a negative and significant relationship between board size and effective tax rates among American firms listed on the NASDAQ 100

From the foregoing, the first hypothesis emerges as follows:

Ho1: Board size has no significant impact on effective corporate tax rates among listed firms in Kenya

\subsubsection{Board Independence and Effective Corporate Tax Rates}

Previous studies have returned conflicting findings on the effect of board independence on effective tax rates. For instance, Khaoula and Ali (2012) in a study of 300 S\&P firms for periods 1996-2009 obtained results showing that board independence improves tax practices. In other words board independence increases effective tax rates. This could be attributed to better monitoring by non-executive directors which deny managers the opportunity to engage in opaque tax avoidance activities.

Pratama (2017) in a study of listed Indonesian companies found that board independence has no significant impact on effective tax rates. The study attributed this to a low percentage of independent directors which makes it difficult for them to conduct proper monitoring.

Zhou (2011) opines that companies with more independent directors are less likely to be affected by tax 
aggressiveness. The study argues that outside directors shield shareholders from managerial opportunism since they represent shareholders interest. Consequently, companies with a high number of non-executive directors would manifest higher rates of effective tax rates.

Lanis and Richardson (2011) in a study conducted on 32 corporations obtained results showing that the number of independent directors has a negative but significant relationship with the bold tax scheme. In other words, the more the number of independent members of board of directors, the less the firm will turn to activities aimed at lowering the effective tax rates. Although this study has been criticized for using a small sample, it nonetheless offers an insight into the relationship between board independence and effective tax rates.

Ribeiro et al. (2015) in analyzing the determinants of effective tax rate using firm characteristics and corporate governance obtained results showing a positive and significant relationship between the number of independent directors and the effective corporate tax rate (ECTR).

Oyenike, Olayinka and Emeni (2016) in their study of 11 listed banks in Nigeria obtained results showing a significant relationship between board independence and tax aggressiveness. This implies that independent directors sitting on the board paly a big role in tax decisions taken by the company.

Accordingly, hypothesis two is formulated as follows:

Ha2: Board independence has no significant impact on effective corporate tax rates among listed firms in Kenya 2.2.3 Board Gender Diversity and Effective Corporate Tax Rates

Kastlunger et al. (2010) state that women play an important role in tax matters. They argue that interpretations of tax laws and regulations differ depending on gender traits. They suppose further that women manifest higher levels of tax compliance than men. Similarly, Aliani, Mhamid and Zarai (2011), report that the presence of female board members influences the tax planning strategy within the company.

In a study conducted by Oyenike et al. (2016) on listed banks in Nigeria in the period between 2012-2014 it was found that although the presence of women on the board is positively related to effective tax rates, the effect is not significant. This is due to the presence of a few women on these boards that hinder them from effectively discharging their role.

Khaoula and Ali (2012) obtained results showing that presence of female directors on the board has no significant effect on effective tax rates, a factor they attributed to low percentage of women on these boards. Equally, Aliani and Zarai (2012a) did not find the presence of women on the board to have a significant impact on tax planning among American firms. This could be attributed to low percentage of female directors which hampers their influence on board decisions.

Aliani et al. (2011) found existence of a positive relationship between board gender diversity and effective tax rates. The study observe in their conclusion that female directors are usually against strategies aimed at lowering effective tax rates within the firm thus work towards increasing tax compliance.

Francis, Hassan, Wu and Yan (2014) conducted a study involving S\&P 1500 firms to find out if female Chief Finance Officers (CFOs) are less tax aggressive. They obtained results showing that female CFOs exhibit lower tax avoidance tendencies compared to their male counterparts. They also compared male-to-female CFO turnover and obtained similar results where there was a transition from a male to a female CFO. This implies that the existence of female directors on a firm's board plays a role in tax decisions.

Boussaidi and Hamed (2015) in a study of 39 Tunisian listed firms obtained results showing a significant and negative link between female directors and tax aggressive actions. They conclude that a higher proportion of women on the board increase the effective corporate tax rate. Similarly, Zemzem and Ftouhi (2013) reported a significant influence on tax aggressive activities by female directors among SBF 120 Index French companies.

Therefore, the third hypothesis for this study is as follows:

Ha3: Board gender diversity has no significant impact on effective corporate tax rates among listed firms in Kenya 2.2.4 Corporate Ownership Structure and Effective Corporate Tax Rates

Corporate ownership structure has been found to be one of the main corporate governance mechanisms that is usually overlooked in the corporate governance literature. The few studies that have been done to show the impact of corporate ownership structure on effective tax rates have returned inconclusive and mixed results. For instance Bradshaw, Liao and Ma (2014) using a sample drawn from publicly traded companies in China found that state owned enterprises exhibit effective tax rates that are significantly higher than those of non-state owned enterprises. These findings suggest that state owned enterprises make tax decisions favourable to the controlling shareholder but costly to the minority shareholders.

Also, Salaudeen and Ejeh (2018) in a study titled "Equity ownership structure and corporate tax aggressiveness" among listed Nigerian firms established a positive but insignificant relationship between the two. The possible explanation for the insignificant results is that majority shareholders may not be effectively monitoring management to ensure they make decisions that are in the interest of majority shareholders.

Studies by Boussaidi and Hamed(2015) and $\mathrm{Li}$ (2014) reported a positive and significant relationship between ownership concentration and effective tax rate. This can be attributed to the fact that the presence of high ownership concentration is likely to make shareholders to closely monitor management due to the huge risk they 
bear. This close supervision denies managers the opportunity to mask their rent extraction activities resulting in higher effective tax rates.

Chen et al. (2010) found out that family ownership can influence company's tax policy. The study concluded that companies with family ownership adopt less bold policies about tax. These findings show that family owners are inclined to prevent tax management in order to avoid reduction of company's share value derived from minority of shareholders' concern about risks of tax activities.

Adhikari, Derashid and Zhang (2006) posit that the true impact of corporate ownership structure on effective tax rates has not been investigated conclusively especially in developing economies. They recommend further research in this area. This study defines ownership structure in terms of either dispersed or concentrated ownership

From the forgoing literature, the fourth hypothesis is:

Ha4: Corporate ownership structure has no significant impact on effective corporate tax rates among listed firms in Kenya

\section{METHODOLOGY}

The study employed longitudinal research design to take care of accruals and deferrals in tax computation. The study population was the 67 firms listed on the Nairobi Securities Exchange as at $31^{\text {st }}$ December 2017 from which a sample of 40 firms was purposively selected based on the criteria captured in table 3.1

Table 3.1 Sample Selection Table

\begin{tabular}{|l|c|}
\hline \multicolumn{1}{|c|}{ Sampling Procedure } & Number of Companies \\
\hline Total listed firms as at $31^{\text {st }}$ December 2017 & 67 \\
\hline Firms with preferential tax treatment & 09 \\
\hline Firms that reported losses in the period & 18 \\
\hline The remaining firms in the sample & 40 \\
\hline
\end{tabular}

Firms with preferential tax treatment are eliminated because they enjoy a lower tax rate than the statutory tax rate of 30\%. Such firms mainly include newly listed firms. Firms that reported losses in the period are excluded from the sample since negative ETR has no meaning. This follows the usual procedure from previous studies (Fernandez-Rodriguez et al., 2019).

Secondary data was extracted from published financial statements for the period 2011 to 2017 using a content analysis form. Data collected was measured as outlined in table 3.2

Table 3.2: Study Variables

\begin{tabular}{lll}
\hline \multicolumn{1}{c}{ Variable } & Abbreviation & \multicolumn{1}{c}{ Measures used } \\
\hline Effective Corporate Tax Rate & ECTR & Cash tax paid divided by Profit Before Tax \\
Board Size & BS & The total number of directors \\
Board Independence & BI & Percentage of non-executive directors on the board \\
Board Gender Diversity & BG & Percentage of female directors on the board \\
Corporate Ownership Structure & COS & Percentage of top 5 shareholding \\
\hline
\end{tabular}

Both descriptive and inferential tests were conducted with aid of STATA software.

The following regression model was used to test the first four hypotheses.

$E C T R_{i t}=\beta_{0 i t}+\beta_{1 i t} B_{1 i t}+\beta_{2 i t} B_{2 i t}+\beta_{3 i t} B G_{3 i t}+\beta_{4 i t} \cos _{4 i t}+\varepsilon_{i t}$

Where;

ECTR - Effective Corporate Tax Rate

$\beta_{0}-$ Constant

$\beta_{1}, \beta_{2}, \beta_{3}, \beta_{4}$, - Coefficient indicating rate of change of Effective Corporate Tax Rate as Board size, Board independence, Board gender diversity and corporate ownership structure changes respectively.

BS - Board size

BI - Board independence

BG - Board gender diversity

COS - Corporate ownership structure

$\varepsilon_{w w w w i t}=$ Error terms, $i=$ Firm 1....., 40, $t=$ Time in years form 2011-2017

\section{RESULTS AND DISCUSSION}

\subsection{Descriptive Statistics}

Table 4.1 presents the descriptive statistics of the variables under study. 
Table 4.1Descriptive statistics of study variables

\begin{tabular}{lcccccc}
\hline Stats & $\mathbf{N}$ & Min & Max & Mean & P50 & Sd \\
\hline ECTR & 280 & 0.000 & 0.739 & 0.247 & 0.252 & 0.149 \\
BS & 280 & 4.000 & 17.000 & 8.975 & 9.000 & 2.308 \\
BI & 280 & 0.167 & 0.941 & 0.800 & 0.818 & 0.125 \\
BG & 280 & 0.000 & 0.500 & 0.161 & 0.167 & 0.125 \\
COS & 280 & 19.440 & 93.03 & 66.398 & 71.090 & 16.377 \\
\hline
\end{tabular}

Source: Research Data, 2019

From the results, the targeted firms have a board with a minimum of 4 members and a maximum of 17 members. On average, there were 9 members on the board (mean $=8.975)$. Out of the total number of directors on the board, $80 \%$ of them are non-executive directors (mean=0.8). The minimum percentage of non-executive directors is $16.7 \%$ and the maximum percentage is $94.1 \%$. The results indicate that boards of NSE listed firms are dominated by non-executive directors. The results of Board gender diversity show that on average women constitutes $16.1 \%$ of total board membership. The minimum percentage is $0 \%$ and the maximum is $50 \%$. It can therefore be deduced that there is a low representation of women on the boards of listed firm in Kenya. Corporate ownership structure is at a mean of 66.398 meaning that the percentage shareholding of top five shareholders was at an average of $66.398 \%$. Minimum shareholding of the top five shareholders is at $19.4 \%$ and the maximum is at 93.03\%. These findings imply that firms listed on the Nairobi securities exchange have to a large extent concentrated ownership.

\subsection{Correlation Results}

The results of the correlation between the variables is presented in Table 4.2

Table 4.2 Correlation Results

\begin{tabular}{|c|c|c|c|c|c|}
\hline & ECTR & BS & BI & BG & $\mathrm{COS}$ \\
\hline ECTR & 1 & & & & \\
\hline BS & $.423 * *$ & 1 & & & \\
\hline BI & $.596 * *$ & $.524 * *$ & 1 & & \\
\hline BG & $.377 * *$ & $.340 * *$ & $.468 * *$ & 1 & \\
\hline COS & $-.162 * *$ & -0.117 & $-.139 *$ & 0.113 & 1 \\
\hline
\end{tabular}

Source: Research Data, 2019

The findings reveal that there was a positive correlation between board size and effective corporate tax rates $(\mathrm{r}=0.423, \mathrm{p}<0.01)$. This means that as board size increases, effective corporate tax rate also increases. The correlation between board independence and effective corporate tax rate is positive $(r=0.596, p<0.01)$ and significant. Furthermore, there is positive correlation between board gender diversity and effective corporate tax rate $(r=0.377, p<0.01)$. This implies that as board independence and board gender diversity increase, effective corporate tax rate also increases. Corporate ownership structure has a negative correlation $(\mathrm{r}=-0.162)$ with effective corporate tax rate and the relationship is significant at $\mathrm{p}<0.01$. This means that as ownership concentration increases, effective corporate tax rate decreases.

\subsection{Hausman Test}

A Hausman test was conducted to determine whether to use random effects model or fixed effects model for regression analysis. This was necessary since panel data was used in the study (Hausman and Taylor, 1978). The results of the Hausman test are presented in Table 4.3. Based on the Hausman Test, random effects model was used to test the hypotheses. 
Table 4.3Hausman Test ---- Coefficients ----

\begin{tabular}{lcccr} 
& (b) & (B) & (b-B) & \multicolumn{2}{c}{ sqrt(diag(V_b-V_B)) } \\
& Fe & Re & Difference & 0.043 \\
BS & 0.158 & 0.148 & 0.010 & 0.048 \\
BI & 0.471 & 0.452 & 0.019 & 0.043 \\
BG & 0.235 & 0.273 & -0.038 & 0.042 \\
COS & -0.105 & -0.136 & 0.031 & 0.0 \\
\hline
\end{tabular}

$\mathrm{b}=$ consistent under Ho and Ha; obtained from xtreg

$\mathrm{B}=$ inconsistent under $\mathrm{Ha}$, efficient under Ho; obtained from xtreg

Test: Ho: difference in coefficients not systematic

$$
\begin{array}{cc}
\operatorname{chi} 2(6)= & (b-B)^{\prime}\left[\left(V_{-} b-V_{-} B\right)^{\wedge}(-1)\right](b-B) \\
= & 3.34
\end{array}
$$

Prob $>$ chi2 $=0.752$

Source: Research Data, 2019

\subsection{Random Effects Model}

The study used the random effects model to test the hypotheses. The results are presented in Table 4.4.

\begin{tabular}{|c|c|c|c|c|c|c|}
\hline & & & \multicolumn{2}{|c|}{ Number of obs } & $=$ & 278 \\
\hline Random-effects GLS regression & & & \multicolumn{2}{|c|}{ Number of groups } & $=$ & 40 \\
\hline Group variable: firmid & & & \multicolumn{2}{|c|}{ Obs per group: $\min$} & $=$ & 3 \\
\hline R-sq: within $=0.5033$ & & & \multicolumn{2}{|c|}{ Avg } & $=$ & 5.5 \\
\hline between $=0.534$ & & & \multicolumn{2}{|l|}{$\operatorname{Max}$} & $=$ & 7 \\
\hline overall $=0.5155$ & & & \multicolumn{2}{|c|}{ Wald chi2(6) } & $=$ & 259.54 \\
\hline $\operatorname{corr}(\mathrm{u} \mathrm{i}, \mathrm{X})=0$ (assumed) & & & \multicolumn{2}{|c|}{ Prob $>$ chi 2} & $=$ & 0.00 \\
\hline ECTR & Coef. & Std. Err. & $\mathbf{z}$ & $\mathbf{P}>\mathbf{Z}$ & {$[95 \%$ Conf. } & Interval] \\
\hline $\mathrm{BS}$ & 0.148 & 0.070 & 2.120 & 0.034 & 0.011 & 0.285 \\
\hline $\mathrm{BI}$ & 0.452 & 0.102 & 4.430 & 0.000 & 0.252 & 0.652 \\
\hline $\mathrm{BG}$ & 0.273 & 0.087 & 3.140 & 0.002 & 0.102 & 0.443 \\
\hline COS & -0.136 & 0.100 & -1.360 & 0.004 & -0.333 & 0.060 \\
\hline cons & -3.399 & 0.672 & -5.060 & 0.000 & -4.715 & -2.082 \\
\hline Sigma_u & 0.293 & & & & & \\
\hline sigma_e & 0.728 & & & & & \\
\hline Rho & 0.139 & & & & & \\
\hline
\end{tabular}

Table 4.4 Random effects model

\section{Source: Research Data, 2019}

The random effects model show that board size, board independence, board gender diversity and corporate ownership structure explain $51.55 \%$ variation in the effective corporate tax rate $\left(\mathrm{R}^{2}=0.5155, \mathrm{p}<0.05\right)$. It implies that $48.45 \%$ variation in effective corporate tax rates is explained by other factors.

\subsubsection{Board Size and Effective Corporate Tax Rate}

The findings show that board size has a positive and significant effect on effective corporate tax rate $(\beta=.148, \mathrm{p}=$ 0.034). The null hypothesis that board size has no significant effect on effective corporate tax rate is thus rejected and it is concluded that, there is up to .148-unit increase in effective corporate tax rate for each unit increase in board size. Consistent with this result, Lanis and Richardson (2011) in a study of the effect of board of director composition on corporate tax aggressiveness found that the level of tax management is significantly affected by board size. The findings are also in support of the results by Ribeiro et al. (2015) which indicated that large boards are related to high effective corporate tax rates. This can be explained by the fact that as the size of the board increases, there is more representation of shareholders' and stakeholders interests which denies managers the opportunity for rent extraction activities such as tax avoidance. Contrary to the results of this study, Aliani and Zarai (2012) found out that there is no significant relationship between board size and effective tax rates. Similarly, Khaoula and Ali (2012) found an insignificant relationship between board size and effective corporate tax rate. 
This could be attributed to the fact that the board was unable to effectively monitor management hence the management made decisions that they deemed fit for themselves.

\subsubsection{Board Independence and Effective Corporate Tax Rate}

Board independence had a positive and significant effect on effective corporate tax rate $(\beta=.452, p=0.000))$. The null hypothesis that board independence has no significant effect on effective corporate tax rate is therefore rejected. The results indicate that for every unit increase in board independence there is 0.452 -unit increase in effective corporate tax rate. This finding is in line with the result obtained by Khaoula and Ali (2012) indicating that board independence increases effective tax rates. The positive effect of board independence on effective corporate tax rate may be due to the fact that the non- executive directors engaged in better monitoring of the management. Further support for this finding is by Ribeiro et al. (2015) who obtained results showing a significant positive relationship between the number of independent directors and the effective corporate tax rate (ECTR). Another study by Oyenike et al. (2016) also shows a significant relationship between board independence and tax aggressiveness. The possible explanation for this is that outside directors shield shareholders and stakeholders from managerial opportunism since they represent the interests of these shareholders and stakeholders. Consequently, companies with a high number of non-executive directors would manifest higher rates of effective tax rates. Contrary to the findings of this study, Pratama (2017) established that board independence had no influence on effective tax rates. The reason for this could be that there was low presence of non-executive directors on the board which limited their influence on board decisions.

\subsubsection{Board Gender Diversity and Effective Corporate Tax Rate}

Board gender diversity had a positive and significant effect on effective corporate tax rate $(\beta=0.273, p=0.002)$. The study therefore rejects the null hypothesis that board gender diversity has no significant effect on effective corporate tax rate. This result suggests that there is up to 0.273 -unit increase in effective corporate tax rate for each unit increase in board gender diversity. This result support that of Boussaidi and Hamed (2015) who in their study of 39 Tunisian listed firms obtained results showing a significant positive effect of board gender diversity on effective tax rates. Similarly, Zemzem and Ftouhi (2013) reported a significant influence on tax aggressive activities by female directors among SBF 120 Index French companies. Aliani et al (2011) also established the existence of a positive relationship between board gender diversity and effective tax rates. The reason for this could be that female directors are usually against strategies aimed at lowering effective tax rates within the firm thus work towards increasing tax compliance. Indeed the finding of this study lends credence to the finding by Kastlunger et al. (2016) that women generally manifest higher level of tax compliance than their male counterparts. Khaoula and Ali (2012) on their part, which is against the finding of this study obtained results showing that presence of female directors on the board has no significant effect on effective tax rates, a factor they attribute to the low percentage of women on the boards. Equally, Aliani and Zarai (2012a) did not find the presence of women on the board to have a significant impact on tax planning among American firms. This could be attributed to low percentage of female directors which hampers their influence on board decisions.

\subsubsection{Corporate Ownership Structure and Effective Corporate Tax Rate}

Corporate ownership structure is shown to have a negative and significant effect on effective corporate tax rate $(\beta=-0.136, p=0.004)$. The study therefore rejects the hypothesis that corporate ownership structure has no significant effect on effective corporate tax rate. According to the findings, an increase in corporate ownership structure by one unit would lead to a 0.136 -unit decline in effective corporate tax rate. Although their exists scanty literature linking the two, this result is in agreement with Fan and Wong (2002). The negative relationship could be explained by the fact that majority shareholders will look for ways of maximizing their after tax income and will therefore induce managers to act in this way. Although Bradshaw et al. (2014) in their study of ownership structure and tax avoidance among Chinese firms reported a negative relationship between the two, the results are insignificant. Also, contrary to the results of this study, Salaudeen and Ejeh (2018) in a study of Equity ownership structure and corporate tax aggressiveness among listed Nigerian firms established a positive but insignificant relationship between the two. The possible explanation for the insignificant results is that majority shareholders may not be effectively monitoring management to ensure they make decisions that are in the interest of majority shareholders. Studies by Boussaidi and Hamed (2015), Li (2014) and Chen et al. (2010) reported a positive and significant relationship between ownership concentration and effective tax rate. This may be attributed to the fact that the presence of high ownership concentration is likely to make shareholders to closely monitor management due to the huge risk they bear. This close supervision denies managers the opportunity to mask their rent extraction activities resulting in higher effective tax rates.

\section{CONCLUSION AND RECOMMENDATIONS}

\subsection{Conclusions}

The study has shown that the average effective corporate tax rate for NSE listed firms is $24.7 \%$ as opposed to the statutory tax rate of $30 \%$. This means that approximately $17.7 \%$ of the expected corporate tax from the NSE listed firms is not paid. The $17.7 \%$ unpaid revenue may be attributed to tax avoidance activities by these firms. 
Evidence from the study suggests that larger boards are associated with higher effective corporate tax rates. One possible explanation is that as the size of the board increases, instances of agency problems are reduced making it harder for management to engage in rent extraction activities of lowering effective tax rates. Larger boards also facilitate better monitoring which is in the best interests of the shareholders and other stakeholders.

The study established that an increase in the number of non-executive directors is associated with high levels of effective corporate tax rate. In other words, the more the number of non-executive directors on the board, the higher the tax paid. The results suggest that non-executive directors tend to maintain a good standing with the tax authorities so that they can gain legitimacy from the society. Additionally, independent directors perform better monitoring thus limiting managerial opportunism.

The findings of the study show that board gender diversity positively influences effective corporate tax rates. The results suggest that the increased presence of female directors on the board leads to higher levels of corporate tax payment. The result also lends credence to the fact that women manifest higher levels of tax compliance than their male counterparts. The implication therefore is that board gender diversity reduces incidences of corporate tax avoidance, thereby leading to increased effective corporate tax rate.

The study reveals that corporate ownership structure has a negative influence on effective corporate tax rate. It implies that the higher the ownership concentration the lower the effective corporate tax rate. It would appear a lower effective tax rate enhances earnings to the majority shareholders and would therefore approve of it but monitor closely how it is done.

\subsection{Recommendations}

The study has shown that the average effective corporate tax rate is $24.7 \%$ as opposed to the statutory tax rate of $30 \%$ indicating incidences of tax avoidance among the listed firms. There is therefore a need for policy makers to review and possibly overhaul the income tax architecture in Kenya with a view of sealing loopholes exploited by the listed firms to lower their effective tax rates. This would lead to enhanced revenue collection thereby cutting on the budget deficits and the growing public debt. Shareholders and investors should also consider ECTR in their evaluation of investment options since it may impact on the long-term value of the firm.

Secondly, the study has indicated that board size has a positive and significant effect on effective corporate tax rates. Policy makers should therefore advocate for larger boards because they offer different skills, views and expertise which enhance the quality of decisions. Larger boards are also difficult to manipulate by management and hence help to deter management from engaging in rent extraction activities such as tax avoidance.

Thirdly, Board of directors with a higher percentage of non-executive directors are associated with higher effective corporate tax rates. Non-executive directors being representatives of shareholders and other interest groups are mindful of the long term survival of the firm and so would not approve activities that could damage the legitimacy and existence of the firm such as excessive tax aggressiveness. There is therefore need for firms to have a higher proportion of non-executive directors so as to enhance tax compliance and maximization of shareholders wealth.

Fourthly, the presence of board gender diversity increases effective corporate tax rate. This means that companies with boards having a higher percentage of women will report higher effective corporate tax rates. There is therefore need for firms to increase women representation on the board since it promotes tax compliance. Policy makers can perhaps set the minimum number of women that should sit on the board.

Fifthly, less concentrated ownership structure exhibit higher effective tax rates among firms listed on the Nairobi Securities Exchange. Since this study established that majority of the listed firms have a concentrated ownership, there is need for policy makers to advocate for dilution in the shareholding of the firms listed on the NSE. This will enhance tax compliance. Also minority shareholders should take a keen interest in tax decisions since it may impact on the legitimacy and long-term survival of their companies due to potential penalties from tax authorities and reputational damage.

\section{SUGGETIONS FOR FURTHER RESEARCH}

This study was limited to firms listed on the Nairobi Securities Exchange. Similar studies can be done using other sets of taxpayers in order to obtain a full picture of the subject matter.

This study found that the ownership structure has a negative and significant influence on effective corporate tax rate. This finding has provided insights on the relationship between the two variables as literature on this two is scanty. Future studies can be conducted to provide more insights regarding the relationship between these two variables.

Furthermore, although the study has rejected the null hypothesis and accepted the alternative hypothesis that board size, board independence and board gender diversity and corporate ownership structure have a significant effect on effective corporate tax rate, there is no evidence that effective corporate tax rate is entirely dependent on the four independent variables. As such further research needs to be carried out to establish what other factors affect the effective corporate tax rate. 
Finally, this study utilized cash tax paid in the computation of effective tax rate. Other studies can use other measures of effective tax rate.

\section{REFERENCES}

Adhikari, A., Derashid, C., Zhang, H., (2006). Political policy, political connections, and effective tax rates: longitudinal evidence from Malaysia. Journal of Accounting and Public Policy 25, 574-595.

Aliani, K., Mhamid, I. and Zarai, M. (2011) Diversité en genre dans le Conseil d'Administration et optimisation fiscale: validation dans le contexte tunisien. Global Journal of Management and Business Research, 11, 4150 .

Aliani,K.. \& A. Zarai, (2012a). Demographic diversity in the board and corporate tax planning in American firms, Business Management and Strategy,3(1), 72-86.

Annuar, H. A Salihu, I. A., \& Sheikh Obid, S. N. (2014). Corporate ownership, governance and Tax avoidance: An interactive effect. Social and Behavioural Sciences ,164,150-160

Bhagat, S., \& Bolton, B, (2008). Corporate Governance and Firm Performance. Journal of Corporate Finance, 14(3), 257-273.

Boussaidi, A. and M. S. Hamed, (2015). The impact of governance mechanisms on tax Aggressiveness: Empirical evidence from Tunisian context. Journal of Asian Business Strategy, 5(1), 1-12.

Bradshaw, M. Liao, G. and Ma, M. (2014).Ownership Structure and Tax Avoidance: Evidence from Agency Costs of State Ownership in China. Available at: http://ssrn.com/abstract=2239837

Chen, S., Chen, X., Cheng, Q., \& Shevlin, T. (2010). Are family firms more tax aggressive than non-family firms? Journal of Financial Economics, 95(1), 41-61.

Crivelli E, De Mooij R, \& Keen M. (2016). Base Erosion, Profit Shifting and Developing Countries. FinanzArchiv: Public Finance Analysis, 72(3).

Desai, M. A., \& Dharmapala, D. (2006). Effective corporate tax rates and high-powered incentives.Journal of Financial Economics, 79(1), 145-179.

Desai, M.A., Dyck, A. \& Zingales, L. (2007). Theft and Taxes, Journal of Financial Economics 84(3), Elsevier, 591-623.

Eisenhardt, K.M. (1989). Agency Theory: An Assessment and Review. Academy of Management Review, 14(1), $57-74$

Fama, E.F. \& Jensen, M.C. (1983) Separation of ownership and control. Journal of Law and Economics ,26, 301325.

Fan, J. and Wong, T. J. (2002). Corporate ownership structure and the informativeness of accounting earnings in East Asia. Journal of Accounting and Economics, 33, 401-425.

Fernandez-Rodriguez, E., Garcia-Fernandez, R. \& Martinez-Arias, A. (2019). Influence of Ownership Structure on the Determinants of Effective Tax Rates of Spanish Companies. Sustainability, 11,1441; doi:10.3390/su11051441

Florackis, C. (2008). Agency costs and corporate governance mechanisms: evidence for UK firms. International Journal of Managerial Finance, 4(1): 37-59

Francis, B.,I. Hasan, Q. Wu \& Yan,(2014). Are Female CFOs Less Tax Aggressive? Evidence from Tax Aggressiveness, Journal of the American Taxation Association, 36(2), 171-202

Government Accountability Office (GAO) (2008). Effective tax rates are correlated with where income is reported. Report to the Committee on Finance U. S. Senate, GAO-08-950, August (United States). Available at http://www. gao. gov/new. items/d08950.

Graham, J.R. (2003). Taxes and Corporate Finance: A Review. Review of Financial Studies, 16, 1075-1129

Hanlon, M. \& Slemrod, J. (2009). What Does Tax Aggressiveness Signal? Evidence From Stock Price Reactions to News About Tax shelter involvement, Journal of Public Economics 93(1-2), Elsevier, 126-141.

Hausman, J.A. \& W.E. Taylor, (1978), Panel data and unobservable individual effects. Econometrica 49, 1377 1398

Jensen, M.C. \& Meckling, W.H. (1976). Theory of the firm: managerial behaviour, agency costs and ownership structure, Journal of Financial Economics, 3(4), 305-360.

Joulfainan, D. (2000). Corporate income tax evasion and managerial Preferences. Review of Economics and Statistics. 82(4), 698-701

Kastlunger, B., Dressler, S., Kirchler, E., Mittone, L. \& Voracek, M. (2010), Sex Differences in Tax Compliance: Differentiating Between Demographic Sex, Gender-role Orientation, and Prenatal Masculinization (2D:4D), Journal of Economic Psychology 31(4), 542-552.

Khamoussi Halioui, Souhir Neifar, Fouad Ben Abdelaziz, (2016) "Corporate governance, CEO compensation and tax aggressiveness: Evidence from American firms listed on the NASDAQ 100", Review of Accounting and Finance, 15(4), 445-462

Khaoula, A. \& Ali, Z.M., (2012). The board of Directors and the corporate tax planning. Empirical Evidence from 
Tunisia. International Journal of Accounting and Financial Reporting, 2(2), 142-157

Lanis, R., \& Richardson, G. (2011). The effect of board of director composition on corporate tax aggressiveness. Journal of Accounting and Public Policy, 30(1), 50-70.

Li, Y. (2014). The Relationship between equity ownership structure and tax aggressiveness of listed companies. Eastern Academic Forum.

Lim, Y. (2011). Tax avoidance, cost of debt and shareholder activism: Evidence from Korea. Journal of Banking and Finance, 35(2), 456-470.

Minnick, K., \& Noga, T. (2010). Do corporate governance characteristics influence tax management? Journal of Corporate Finance, 16(5), 703-718.

Mutua, J.M., (2012). A Citizen's Handbook on Taxation in Kenya. Nairobi: Institute of Economic affairs.

Nekesa, M. O., Namusonge G. S., Makokha E.N (2017). Effect of Corporate Income Tax on Financial Performance of Companies Listed on the Nairobi Securities Exchange in Kenya. International Journal of Social Sciences and Information Technology, 3(7), 2467

Oyenike, O., Olayinka, E. \& Emeni, F. (2016). Female Directors and Tax Aggressiveness of Listed banks in Nigeria. $3^{\text {rd }}$ International Conference on African development issues. ISSN:2449-075X

Pomerleau K., \& Jahnsen K. (2017). Corporate Income Tax rates around the World. Tax Foundation, Fiscal fact No. 559

Pratama A. (2017). Company Characteristics, Corporate Governance and Aggressive Tax Avoidance Practice: A Study of Indonesian Companies. Review of Integrative Business and Economics Research, 6(4), 70-81.

Ribeiro, A., Cerqueira, A., Brandao, E. (2015). The Determinants of Effective Tax Rates: Firms' Characteristics and Corporate Governance. FEP Working Papers 567, ISSN: 0870-8541, School of Economics and Management, University of Porto.

Salaudeen, Y.M. \& Ejeh, B.U.(2018). Equity ownership structure and corporate tax aggressiveness: The Nigerian context. Research journal of Business and Management,5(2), 90-99

Shleifer, A. \& Vishny, R.W. (1997). A Survey of corporate governance. Journal of Finance, 52, 737-783

The Institute of Certified Public Accountants of Kenya (ICPAK) (2016). Kenya's Revenue Analysis 2010-2015: A Historical Perspective to Revenue performance in Kenya: Nairobi, Kenya

Zemzem, A. \& Ftouhi, K. (2013). The effects of board of directors characteristics on Tax aggressiveness. Research Journal of Finance and Accounting, 4(4), 140-147

Zhou, Y. (2011), Ownership Structure, Board Characteristics, and Tax Aggressiveness, PhD, University Hong Kong. 